\title{
The Use of Science in Wildland Fire Management: a Review of Barriers and Facilitators
}

\author{
Molly E Hunter ${ }^{1} \cdot$ Melanie M Colavito $^{2} \cdot$ Vita Wright $^{3}$
}

Published online: 10 October 2020

(C) The Author(s) 2020

\begin{abstract}
Purpose of Review Science plays a critical role in natural resource management, and the use of science in decision-making is mandated by several policy initiatives. Other disciplines have documented the challenges associated with applying science to management and possible solutions to overcoming challenges, but the evaluation of science use in wildland fire management is relatively immature. In this paper, we reviewed the available literature that evaluates science use in wildland fire management and common barriers and facilitators to science use in decision-making.

Recent Findings We developed a conceptual model that describes the possible uses of science in fire management (perception, planning, forecasting, implementation, assessment, communication, and policy), common barriers to science use (lack of science, uncertainty, funding/capacity, conflict), common facilitators to fire science use (collaboration, trust, boundary organizations, coproduction), and factors that can act as facilitators or barriers to science use depending on their presence or absence (awareness, accessibility, relevance). In the context of our conceptual model, we reviewed 67 papers that examined fire science use between 1986 and 2019.

Summary Most studies were conducted in the USA in the last 10 years and demonstrated that science is commonly used in fire management and that the maturation of organizations devoted to science translation and communication in the last 10 years has likely facilitated the application of fire science. The evaluation of fire science use, however, is still relatively immature, with studies needed on the use of fire science in countries outside the USA, the use of science in the management of wildfires, and in the crafting of policy related to wildland fire management.
\end{abstract}

Keywords Science application · Co-production $\cdot$ Collaboration $\cdot$ Fire science

\section{Introduction}

\section{Background and Purpose of Review}

This article is part of the Topical Collection on Fire Science and Management

Molly E Hunter

mhunter@blm.gov

Melanie M Colavito

Melanie.colavito@nau.edu

Vita Wright

Vita.wright@usda.gov

1 Joint Fire Science Program, School of Natural Resources \& the Environment, University of Arizona, Tucson, AZ, USA

2 Ecological Restoration Institute, Northern Arizona University, Flagstaff, AZ, USA

3 USDA FS Rocky Mountain Research Station, Missoula, MT, USA
Science, or the systematic pursuit of knowledge and understanding of the natural and social world through experiment and observation, has long played a critical role in the management of natural resources. In the last century, the relative importance of science in land management decision-making has been paramount as evident in the broad acceptance of "scientific management" [1] and the many policy mandates for use of "best available science" (e.g., 1973 Endangered Species Act, 2012 Forest Planning Rule) [2••]. Over time, more emphasis has been placed on the role of other forms of knowledge (e.g., local knowledge, traditional ecological knowledge), collaborative governance, and other factors in informing land management decisions [1]. Nonetheless, science continues to plays a critical role in decision-making and is particularly critical for reducing uncertainty and enhancing credibility. 
The presence of science alone does not guarantee its application. Certain factors need to be in place for science to have utility to end users. These include salience (e.g., relevant to land management decisions), credibility (e.g., technically robust), and legitimacy (e.g., unbiased) [3], conditions which are not always present in scientific studies. In addition, decisionmakers need to be aware of relevant science and understand how to properly apply their findings, which can be a significant challenge when the body of available science is large, confusing, or has uncertain implications $[4,5]$. Scientific findings can also conflict with other values related to the management of natural resources [6].

Certain entities and processes can help overcome barriers to science applications. The presence of boundary organizations, which are designed to translate science, facilitate the development of new science relevant to decision-making, and improve communication and collaboration among scientists and users of science, can accelerate the use of science in decision-making [3]. Boundary organizations and collaborative research processes that involve scientists and managers can also lead to the production of boundary objects, which are tools (e.g., decision support tools, workshops) that can help professionals from different groups negotiate knowledge transfer [7] and represent different viewpoints of those involved in their production [8]. Improved communication and collaboration among scientists and science users can ultimately lead to co-production of knowledge, whereby scientists and science users collaboratively engage in the scientific process, including formulating research questions, methods, analysis, and disseminating results [9]. Coproduction in science can take on many different forms [10], but the general principles, including ongoing twoway communication among scientists and science users, have been demonstrated to increase the likelihood that science will be used in decision-making [11].

Relative to other fields (e.g., climate change adaptation), the evaluation of the use of science for the management of wildland fire is immature. Only recently have investigators begun to study the use of fire science and barriers and facilitators of its application [2, 12-14]. A surge in research into the application of fire science has likely been spurred in part by the establishment of the Fire Science Exchange Network (FSEN) in 2009, a boundary organization in the USA funded by the Joint Fire Science Program (JFSP) and devoted to accelerating the adoption of fire science [15••], as well as policy changes following destructive wildfires (i.e., bushfires) in Australia that spurred efforts to better incorporate science into fire management [16]. Since this emerging body of work has not been synthesized, the purpose of this study was to review the scientific literature on the use of science in wildland fire management and to identify factors that act as barriers or facilitators to fire science application.

\section{A Conceptual Framework for the Use of Fire Science}

To frame our investigation of the literature, we first developed a conceptual model for how science is used in wildland fire management and factors that may act as barriers or facilitators (or both) (see Fig. 1). This framework was developed a priori based on our own knowledge and experience of wildland fire science and management $[2,12-14]$ and the use of science in other areas of natural resource management.

According to the US National Wildfire Coordinating Group (NWCG), fire management includes "all activities for the management of wildland fires to meet land management objectives. Fire management includes the entire scope of activities from planning, prevention, fuels or vegetation modification, prescribed fire, hazard mitigation, fire response, rehabilitation, monitoring, and evaluation" [17]. Thus, fire management encompasses both fuels management and wildfire management. For the purpose of this paper, we consider fuels management as the manipulation of living and dead vegetation to promote desirable fire behavior and meet other resource management objectives. We consider wildfire management as the use of firefighting resources in suppression or containment of human- or naturally caused wildfires if they threaten valued resources, or the monitoring or facilitation of spread of naturally caused wildfires if they are beneficial to valued resources. There is some degree of overlap in management of fuels and wildfire. For example, managers who implement prescribed fires for the purpose of fuels reduction often work in wildfire management. Managers in fuels and wildfire, however, are largely encompassed in separate groups

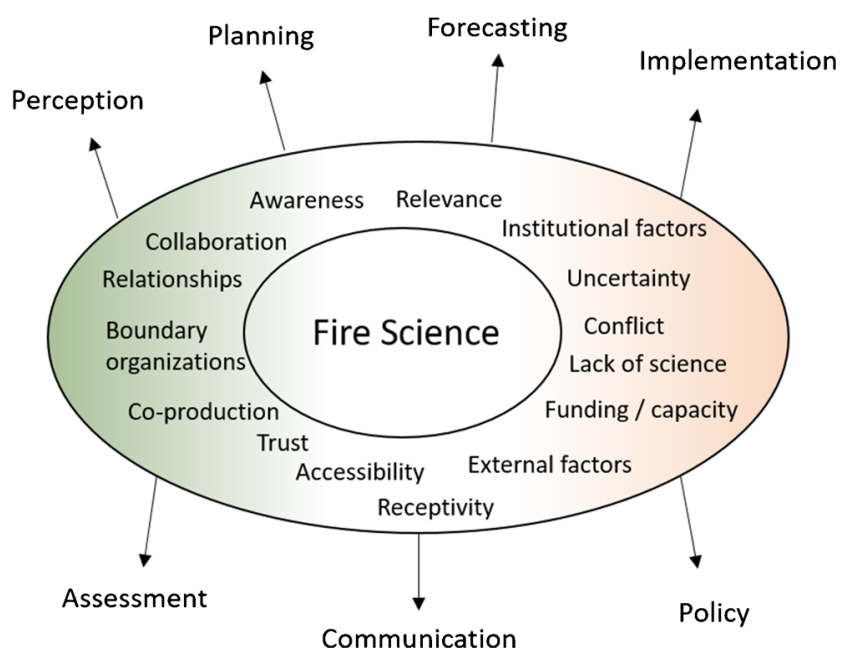

Fig. 1 Conceptual model of the potential uses of fire science (perception, planning, forecasting, implementation, assessment, communication, policy) and possible barriers and facilitators to science use (inner circle). Factors in the right side of the inner circle are more likely to act as barriers when present. Factors on the left side are more likely to act as facilitators when present. Factors in the middle can act as facilitators or barriers depending on their presence or absence. This conceptual model can be applied to fuels or wildfire management. See text for descriptions of specific barriers and facilitators to science use 
specializing in either fuels or operations and using different temporal scales and processes for decision-making. Decisionmaking in fuels management occurs over long time-frames (often years) largely under the guise of national policies that dictate reducing wildfire risk, restoring ecological processes, promoting resilience, and preventing environmental degradation (e.g., National Environmental Policy Act, National Forest Management Act, National Fire Plan, Endangered Species Act) $[18,19]$. Decision-making in wildfire management occurs over short time frames (days to weeks) under the structure of the Incident Command System [20] and with common objectives of promoting firefighter safety, minimizing damage and losses to valued resources, and utilizing fire as a natural ecological process where appropriate.

Both fuel and wildfire managers use science from multiple disciplines in decision-making. For example, fuel managers may consult science in wildlife biology, forestry, and ecology when planning fuel treatments that reduce wildfire risk while maintaining or enhancing wildlife habitat [18]. Wildfire managers regularly consult meteorologists to forecast potential wildfire behavior, spread patterns, and impacts to valued resources [21•]. However, the full scope of science use in wildland fire management has not been described or evaluated. Based on our own understanding and experience in wildland fire science and management, our conceptual model details broad potential uses of science (perception, planning, forecasting, implementation, assessment, communication, and policy) and a multitude of potential barriers or facilitators to the use of science (Fig. 1). In this model, factors shaded in red are those that are more likely to act as barriers to science use, factors shaded in green are more likely to be facilitators of science use, and unshaded factors could act as facilitators or barriers, depending on their presence or absence.

In this model, science use can entail altering a user's perception of an emerging management issue. For example, science related to climate change or the spread of invasive species may cause an end user to think about how management practices may need adjustment in the future. Science use for planning could include consultations with scientists or the scientific literature in the development of fuel treatment plans or use of forecasting tools to determine seasonal firefighting resource needs. Science may be used in forecasting, or the prediction of future conditions to inform current or future management practices. Decisions related to implementation may be more tactical and short term in nature. Examples could include using science-based decision support tools to develop specific parameters (e.g., weather and fuel conditions) under which to conduct a prescribed fire or burnout operation. Assessment includes the evaluation of management actions or monitoring existing conditions. Science frameworks are likely needed to assure that assessment in wildland fire management is robust. Science may be consulted in the communication of management goals, objectives, or decision frameworks with multiple audiences (e.g., public, stakeholders, administrators, policy-makers). Finally, science might be used in the crafting of policy related to wildland fire management at national, state, and local levels. Some examples of enacted policies related to wildland fire management include the 1995 fire-policy revision and the National Fire Plan in the USA [22], and the "5\% policy" in Australia [23].

Common barriers to the application of fire science in the conceptual model described above include institutional factors within fire management organizations (e.g., existing policy, bureaucratic hurdles) that can impede the application of fire science. Application of science can be halted if there is a lack of science relevant to fire management or uncertainty associated with the science findings or how to apply them to fire management. Agencies often lack funding or capacity (e.g., resources, scientific expertise, time) to keep abreast of scientific studies and devise strategies for applying science. There also can be external factors (e.g., public acceptance, litigation) that deter land management agencies from adopting fire science when there is a perception that it conflicts with the values of specific entities external to fire management organizations. Finally, fire science findings can be in conflict with internal agency policies, external values, or other scientific studies, all of which can prevent the application of fire science.

Some of the above factors can also act as facilitators to the application of fire science under certain conditions. Institutional factors can act as facilitators to fire science use, for example, when changes in agency policy dictate the use of fire science. Our conceptual model proposes that there are a number of factors that tend to be equally identified in the literature as barriers or facilitators to the use of fire science, depending on their presence or absence (Fig. 1). The relevance of fire science to management decisions (e.g., appropriate spatial and temporal scale) acts as a facilitator to science use when indeed fire science is relevant to management but a barrier when it is not. Awareness of fire science on the part of intended users of science is a facilitator when decision-makers are aware of relevant science and a barrier when they are not. Other factors tend to have the same dichotomy, including accessibility, or the availability of science to intended users in useful formats, and receptivity, or the beliefs of intended end users on the utility of science.

The left side of the conceptual model lists several factors which can act as facilitators to the use of fire science (e.g., coproduction, boundary organizations) (Fig. 1). In a general sense, strong relationships among scientists and users of science can foster trust among managers and scientists. Collaboration and co-production on research and management projects can lead to further trust in the science findings on the part of managers. These factors have proven to be successful in accelerating the adoption of science in other areas of natural resource management [9]. The role of 
boundary organizations in facilitating this cycle and disseminating science has proved to be paramount [3].

\section{Methods}

To address our research question, we limited our review to papers that address fire science application explicitly as a driving study question or more implicitly as an emergent study finding. For example, a number of publications from other fields, such as forest management and climate science, were included in our review because findings emerged from those studies that were relevant to wildland fire management. This review did not include papers that present fire science findings or decision support tools for wildland fire management unless the papers also included some discussion about the use of that science and whether or not the findings or tools were being used in fire management. We also asked secondary questions as part of this systematic review, including what methods were used to assess fire science application, what type of paper was used to present the findings (e.g., gray literature, peerreviewed publication), where was the research conducted, what wildland fire management topics were addressed, and what elements of wildland fire management were being assessed (Fig. 1).

We used the Google Scholar database to search for papers published before May 2019 using the following keywords: "wildfire and science use," "use-inspired science and wildfire," "co-production and science and wildfire," "fire science application," and "barriers and fire science and application." We compiled those studies that addressed in some capacity the application of fire science in management, including how science is used and factors that act as barriers or facilitators to the use of fire science. We also "chased" compiled articles forward and backward in time by examining their references cited and using the "cite by" feature in Google Scholar to find references that cite the compiled articles [24]. A few additional articles published in 2019 were also included due to their relevance. See Appendix A for a complete list of citations by their general topic categories and year of publication in our review.

In order to compare citations, we developed a spreadsheet to track the following aspects of each paper: (1) whether or not papers directly addressed the use of fire science as a study question or whether the use of fire science emerged as a finding from another line of inquiry; (2) whether the paper used quantitative or qualitative methods or both or whether the paper was anecdotal (e.g., based on personal observation or opinion); and (3) basic information about the type of article (e.g., peer-reviewed or gray literature), topic(s) (e.g., fuels management, climate change), and location. In addition, we tracked the degree to which papers assessed aspects in our conceptual model, including how science is being used (e.g., perception, planning, forecasting, communication, implementation, assessment, policy, or other uses) and factors that act as barriers or facilitators (or both) to science use (e.g., external, institutional, relevance, funding/capacity, relationships, coproduction or collaboration present in some capacity, boundary organization presence, science accessibility). Each paper was reviewed for all aspects listed in our conceptual model, but not all of the papers addressed all of these aspects, and some of the aspects were captured in a general "other" category if they were not part of our original conceptual model. In the results, some aspects are combined because of considerable overlap in context (e.g., collaboration and coproduction).

All of the papers were coded according to each aspect in the conceptual model (e.g., how science is used and identified barriers or facilitators to science use). In order to ensure reliable coding across two coders, the first five papers were coded by one coder and the second five papers were coded by the second coder. Statistically significant intercoder agreement was not obtained [25]. Each coder then reviewed the other coder's work to ensure that they were interpreting each paper according to the conceptual model in the same way. The two coders then discussed their interpretations and adjusted the coding in the spreadsheet accordingly. After agreement between the two coders was achieved, the rest of the papers were coded only once by one of the two coders. After coding was complete, the different aspects of the conceptual model were compared by all three authors using descriptive statistics and over the time span of the articles in order to identify themes and patterns in the review.

\section{Results/Discussion}

\section{Overarching Study Trends}

We found 67 papers that address the application of fire science in some capacity. The earliest papers we found on the use of fire science were an anecdotal study published in 1986 [26] and a Master's thesis from 1987 [27]. Since then, both the number of papers and the number of papers published in peer-reviewed journals have increased over time, especially after 2010 (Fig. 2). The quality of evidence has also increased over time as more investigators have used quantitative and qualitative methods to assess the use of fire science, as opposed to relying on anecdotal approaches (Fig. 3). The vast majority of authors investigated the use of fire science in the USA, with only seven studies conducted in Australia, five in Canada, and three in Europe. Many of the reviewed papers (32) focused specifically on the use of fire science, including in assessing firefighter safety, reducing wildfire risk, and managing post-fire landscapes. Other reviewed papers examined the use of science in a broader context, such as land 
Fig. 2 Number of papers published each year that address the application of fire science in some capacity. Gray literature includes studies published in technical or other reports, conference proceedings, popular publications, and book chapters. Peer-review includes studies published in peer-reviewed scientific journals



management more generally (15) and climate change (12), yet presented results related to fire science within these contexts. Fewer papers (8) specifically examined the application of fire science in relation to the use of science-based decision support tools. Most of the 67 papers addressed the use of fire science in the context of fuels management (37) rather than wildfire management (9). For the remaining papers (21), the management context (fuels vs. wildfire management) was either not readily apparent or both contexts were addressed.

Given the sharp increase in number and quality of studies after 2009, we summarize and present results for two time periods: 1986-2009 and 2010-2019. The increase in number and quality of papers over time likely reflects a growing interest in factors that influence science use and increased investment on the part of land management agencies in programs that accelerate the adoption of science in natural resource management. Recognizing the need to advance the use of science by natural resource managers, some agencies have established boundary organizations [28] for this very purpose. Most notably for fire, this includes the JFSP FSEN [4]. Other relevant boundary organizations in the USA include the National Oceanic and Atmospheric Administration's Regional Integrated Sciences and Assessments (RISA) established in 1995 [29] and the Department of Interior Landscape Conservation Cooperatives established in 2009 [30]. In British Columbia, the non-profit Forest Research Extension Partnership (FORREX) provides access to science to support sustainable natural resource management decisions
Fig. 3 Number of papers published in each year that utilize anecdotal, qualitative, quantitative, or both quantitative and qualitative methods in investigating the application of fire science in management. Anecdotal refers to methods that rely on personal observation. Qualitative refers to studies that utilize interviews, focus groups, or similar instruments to better understand the nature of fire science use. Quantitative refers to methods that utilize surveys or similar instruments to quantify some aspect of fire science use

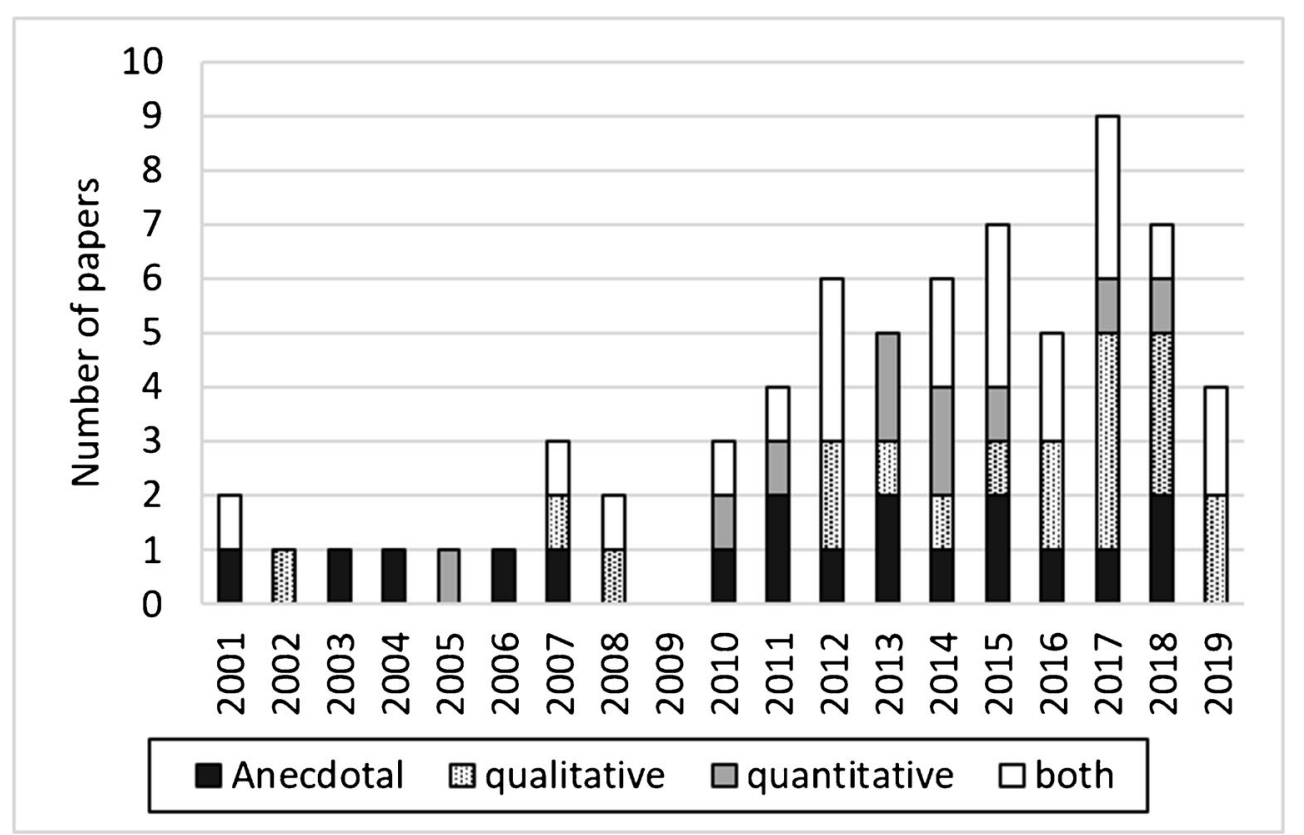


Fig. 4 Number of papers in two time periods (1986-2009 and 2010-2019) that identify specific points in the wildfire management cycle where fire science is utilized

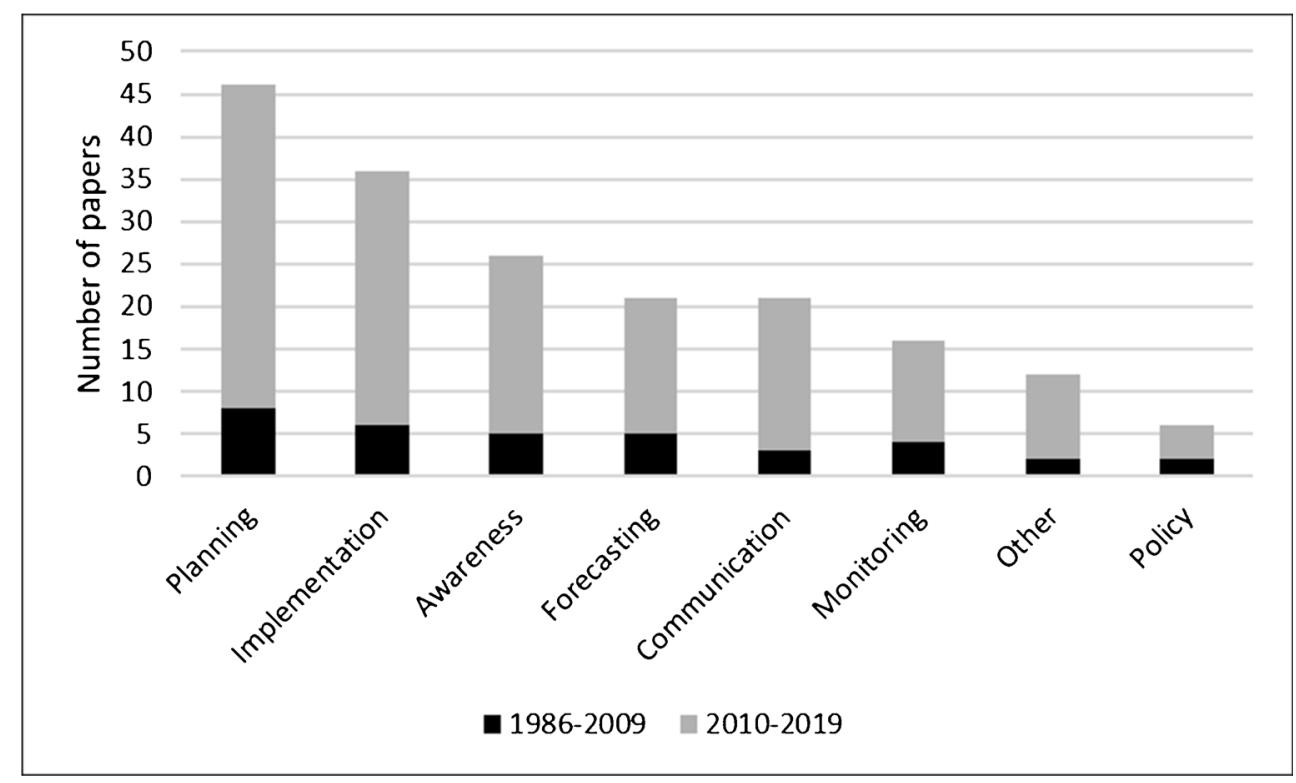

to government, non-government, aboriginal, academic, and industry partners [31]. In Australia, Bushfire and Natural Hazards CRC (www.bnhrcrc.com/au; accessed 8/27/2020) plays a similar role of provided relevant fire science to end users. These organizations have provided opportunities to evaluate factors that influence the application of fire science by land managers and contributed to the growing body of work in fire science application.

All of the papers we reviewed acknowledged and/or documented that fire science is used in land management in some capacity. Authors most commonly identified land management planning and implementation of management activities as times in which fire science is used to inform manager decisions (Fig. 4). This is consistent with findings from other studies [12-14] and perhaps is not surprising, given that many US policies dictate the use of science in planning $[12,14,32$,
33]. Other common uses of science include increasing perception of emerging fire science issues, forecasting, and developing communication strategies or assessment protocols. For example, output from a relatively new wildfire decision support tool in Australia was used to communicate science to the public, policy-makers, or managers [23, 34]. Very few studies have documented the use of fire science to inform policy. This could reflect a need for increased use of fire science to inform policy-making or a need to explicitly study how fire science is or is not utilized in policy settings.

\section{Common Barriers to Fire Science Application}

The most commonly identified factors identified as barriers to fire science use are shown in Fig. 5. Factors external to fire management agencies were most often cited as barriers to the
Fig. 5 Number of papers in two time periods (1986-2009 and 2010-2019) that identify how external factors, funding/capacity, and institutional factors acts as either a barrier, facilitator, or both a barrier and facilitator to the application of fire science




application of fire science (Fig. 5). These include a lack of public awareness of science and lack of public support of specific fire management approaches [12, 35-42], a perception by managers that science conflicts with policy or political agendas, a perception that science itself is politically motivated [43, 44], and concerns that new approaches will be litigated [41]. Lack of funding/capacity and institutional factors was also commonly listed as barriers to science use (Fig. 5). Only four studies identified lack of science as a significant barrier to science use [25, 45-47].

Lack of funding/capacity (including time) was commonly reported as a barrier to fire science application in publications across time periods and across geographic areas $[4,12-14,40$, 48-50]. Thirty-four papers mentioned resources or capacity as either barriers (28), facilitators (5), or both (1) (Fig. 5). Resource management specialists across five federal agencies identified capacity problems as a barrier to using new research [36]. Similarly, two studies of fire managers in the USA found that they were more likely to face capacity barriers, such as lack of time, funding, and personnel, than problems with the quality or availability of data $[14,51]$. A recent case study of one of the JFSP Fire Science Exchanges acknowledged the importance of institutional support and funding as facilitators for fire science

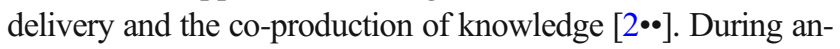
other case study, managers recommended staffing solutions, including the designation of staff whose responsibilities would be to filter research information, the designation of a research liaison, and/or a research assistant, who would be responsible for seeking scientific information on specific topics [40].

In addition to time and resources, authors noted that, in order to apply science, managers need an institutional structure that supports innovation. This includes processes for integrating new approaches into management and the flexibility to experiment with new approaches. Discussing barriers to the application of new wildfire risk management tools, Calkin et al. [38] cited research [52] that found innovation and risktaking were among the least rewarded traits for decisionmakers. Others acknowledged that the management authority inherent in bureaucracies can compromise adaptability, the absence of mechanisms for linking learning to implementation decisions, and lack of review processes that integrates science and monitoring information [32, 46, 50]. Potential solutions include developing incentives and rewards for applying fire science and adopting adaptive management processes [32, 53]. Early papers that recognized institutional factors within fire management agencies most often referred to them as barriers to the application of science ( 6 of 8 papers). Later papers also predominantly cited institutional factors as barriers (16 of 31 papers), but a growing number of papers acknowledged that institutional factors can be facilitators ( 9 of 31 papers) or they can act as both barriers and facilitators (6 of 31 papers) (Fig. 5). This could reflect institutional investment in capacity for applying science.
Organizational culture can be an overriding influence on many of the institutional barriers and facilitators mentioned. Organizational members often behave based on shared values, beliefs, and assumptions more than rules [54]. Wright [55] applied the Garvin et al. [56] survey of learning organization characteristics to 495 fire managers and decision-makers in three US federal fire organizations, measuring psychological safety, openness to new ideas, appreciation of differences, analysis, information transfer, and time for reflection. Survey respondents indicated they felt psychologically safe introducing new ideas in their work units; however, they were less certain new ideas would be integrated into existing approaches. Compared with individual experiences and perceptions, work unit and agency culture were not significant determinants of research use by fire managers [55]. Further study is needed to assess whether and how organizational culture affects the use of fire science.

Other factors identified as barriers to science use were science uncertainty, conflict, and awareness. Sixteen papers cited uncertainty or conflict around science findings as a barrier to fire science use. This includes science that is incompatible with management approaches or agency directives, or science findings that are confusing or inconclusive. Of the twelve papers that examined the use of fire science in the context of climate change, a relatively high proportion (6 papers) identified scientific uncertainty or conflict as a barrier. This may reflect the fact that climate change science often relies on environmental modeling exercises that include downscaling of climate projects, and many studies report that managers are uncertain or skeptical of such methods $[57,58]$. In the realm of fire science, scientific uncertainty or conflict can arise from a lack of synthesis of the scientific literature [59], lack of science in a particular locality [46], or lack of trust in the outcome of studies that rely heavily on modeling and assumptions [34]. Ten papers identified lack of awareness or understanding of science by managers as a significant factor in determining the use of fire science in decision-making. For example, a survey and interview with boundary spanners in fire management indicated that some wildland fire managers did not use science because they were not aware of relevant fire science [13].

\section{Common Factors Acting as Barriers and Facilitators to Fire Science Application}

Two of the most common factors identified for influencing the use of science were the accessibility of science to managers (46 papers) and relevance of science to management concerns (41 papers). These factors were identified as both facilitators and barriers to the application of fire science (Fig. 6). Generally speaking, when fire science was highly relevant to management needs and easily accessible to managers, these were identified as facilitators to the application of fire science. 
Fig. 6 Number of papers in two time periods (1986-2009 and 2010-2019) that identify how the accessibility of science to managers, the relevance of fire science to management needs, and the receptivity of managers to science acts as either a barrier, facilitator, or both a barrier and facilitator to the application of fire science



They were identified as barriers when these conditions were not in place. For example, Garfin et al. [60] documented how seasonal weather forecasts are heavily relied upon in fire management, partly because the spatial and temporal scales of forecasts are relevant to fire management decisions and the forecasts are distributed in multiple formats. In contrast, other authors suggested that decision support tools are not used because managers are not interested in the topics they address [42], or that fire managers believe many scientific studies are not relevant to their locality, and that the sheer volume of studies and lack of synthesized works makes the science effectively inaccessible $[36,44]$.

While we cannot determine statistically significant differences between time periods, it is interesting to note that only a small proportion of papers published between 2001 and 2009 listed science relevance and accessibility as facilitators of science, whereas much higher proportion of papers published between 2010 and 2019 identified these factors as facilitators of science use (Fig. 6). This trend could reflect increased investment in organizations that span boundaries between scientists and managers or increased attention to evaluating the use of fire science. Whether seen as barriers or facilitators, the results show that fire science is often, but not always, seen as relevant to manager needs and accessible to them [13]. Nonetheless, issues of science relevance and accessibility remain. For example, while there is great promise in application of remote sensing tools in fire management, spatial and temporal scales are not always consistent with fire management needs, and managers have difficulty learning about newly available tools [49].

Personal receptivity to science can also be a barrier or facilitator to science application. This includes individual innovativeness, educational and professional backgrounds, beliefs about research ease of use and usefulness, attitudes toward science, and stress levels that can hinder creativity [14, 40,
$42,55]$. Many papers in both periods recognized individual differences in receptivity to scientific innovations suggested receptivity was a barrier; however, some papers were more optimistic, noting that differing receptivity also can be a facilitator of science application (Fig. 6). Wright [14] and Kaage [27] suggested that understanding audiences, in particular identifying innovativeness and early adopters within the fire management organization, can be used to more effectively deliver science to potential users.

\section{Common Facilitators to Fire Science Application}

Authors that referred to relationships, co-production (or collaboration), boundary organizations, and boundary objects largely discussed these factors as facilitators to fire science application. Multiple papers address the importance of relationships between scientists and managers or decision-makers for facilitating the use of science [14, 51, 55, 61-63]. For example, two studies noted that direct engagement and experience with scientists created more support for and use of science by managers $[55,64]$. Other studies illustrate the importance of face-to-face and in-person interactions for fostering relationships $[12,65,66]$. Only 2 of the 33 papers that discussed relationships described it as a possible barrier. For example, Neale and May [67••] discussed how relationships can suffer due to communication breakdowns, and Kearns and Wright [40] discussed issues that arise when relationships with scientists are not present. Kemp et al. [41] also noted that relationships are a facilitator to the use of science when they are present, which implies that a lack of relationships is a barrier. Relationships were also proposed as a way to address other barriers in land management planning and collaboration $[58,68]$. Furthermore, relationships and trust are important precursors to processes like the co-production of knowledge or collaboration in research [69]. 
In 1987, Kaage [27] suggested involving practitioners in the development of research would increase practitioner ownership of new ideas and improve research and manager opinions of each other. The concept of co-production (also referred to as collaboration in some of the publications) has received increasing attention in the papers we reviewed over time, especially since 2010 (Fig. 7). The increased use of the concept has created some confusion about what exactly co-production entails [70] or when it is the most appropriate tool for facilitating the use of science [71]. Co-production is time intensive and requires significant capacity that is not always available, especially in fire management, so it can be a prohibitive approach unless it is facilitated through a boundary organization, which can dedicate the necessary attention and effort to deliberately facilitating co-production to produce actionable science [2••]. Nonetheless, in the papers that we reviewed, it is largely discussed in a positive light. For example, Allen et al. [57] note that co-production is now desired by some research participants, Kemp et al. [41] emphasize that science that is informed by the context in which the intended end users of that science operate can be used more effectively, and Archie [68] notes that it can be used to address other barriers to the use of science in land management planning and collaboration. Garfin et al. [60] describe how the principles of coproduction can be used to get managers and scientists working together to increase the use of seasonal forecast science. Only one of the studies that we reviewed discussed both barriers and facilitators to collaborative or co-produced approaches [36]. Only 3 of the 24 articles we reviewed that addressed co-production used quantitative methods, 13 used either qualitative or mixed-method approach, and 8 of them used anecdotal approaches. This highlights the difficulty of measuring the outcomes of co-production or collaboration, though there is a growing effort to better evaluate co-production of knowledge processes and outcomes [63, 72]. Furthermore, coproduction of knowledge is one of many approaches to collaboration around the development and use of science for decision-making, and more work is needed to really understand its outcomes $[10,63]$.

Similar to the authors that discuss relationships and coproduction, the 23 papers that discussed boundary organizations largely presented them as facilitators to the use of fire science. Notably, only one paper included a discussion of boundary organizations in the literature we reviewed in the 1986-2009 time period (Fig. 7). In the last 10 plus years, the term "boundary organization" has become more institutionalized in fire science and management, due in part, to the work of the JFSP FSENs. These were not established until 2009, and they are dedicated to facilitating the use of fire science by managers. The first foundational paper assessing the FSENs was not published until 2012 and noted that the FSENs are important for consolidating information and improving the connections between scientists and managers [4]. However, the FSENs have received increasing attention as boundary organizations in recent years, particularly with respect to their evaluation of intended outcomes [15••], unique engagements with managers [66], and deliberate use of co-production [2••]. The role of the NOAA RISAs in assisting with the use of fire science for predictive services and fire-related meteorology has also received more attention in recent years [60]. Some papers suggest that boundary organizations and boundary spanners, the individuals who work in boundary organizations and play intermediary roles, often represent a trusted source of scientific information [62] and can be helpful in facilitating collaborative groups that are trying to use science to come to consensus on complex landscape management concepts that affect wildland fire [2, 47].

Some authors that discussed boundary objects tended to have more reservations about their role in facilitating the use of fire science. For example, 3 of the 20 papers that discussed boundary objects discussed them as possible barriers $[42,43$, 73 ] and another 3 discussed boundary objects as both potential
Fig. 7 Number of papers in two time periods (1986-2009 and 2010-2019) that address relationships (or trust), coproduction (or collaboration), and boundary organizations




barriers and facilitators of fire science use [44, 74, 75]. Boundary objects can be amorphous and range from workshops [76] to decision-support tools [22, 38, 59], so their use and outcomes vary depending on the type of boundary object under consideration. For example, with boundary objects like wildfire risk maps $[74,75]$, the utility for management is mixed depending on how managers were engaged in the map development. Other authors noted that boundary objects like risk models or decision-support tools can be complex and difficult to use without support from experienced practitioners or strong visual outputs [34, 42]; therefore, managers who perceive innovations as difficult to use may not use them without adequate training and support $[14,42,45]$. During a series of fire-climate workshops, fire managers suggested that fire-climate science and decision support tools could be taught through training courses [45]. Additionally, when decisionsupport tools and models are simplified and modified with manager input, they can become easier to use in fire management $[66,77]$.

\section{Conclusion}

The available body of work on the application of fire science shows that fire science is indeed used in decisionmaking in wildland fire management. For our conceptual model of fire science use (Fig. 1), there is more evidence for fire science use in certain aspects of wildland fire management (e.g., planning, forecasting) than others (e.g., assessment, policy). There is also more evidence for the use of fire science in fuels management as opposed to wildfire management. This most likely reflects a lack of scientific studies on the use of fire science in these areas rather than a lack of science use. It is possible that the factors governing the use of fire science in, for example, policy development and wildfire management are different from those in planning or fuels management. Thus, we recognize a need for additional studies on the use of fire science in understudied aspects of our conceptual model, particularly the use of fire science in policy, assessment, and all aspects of wildfire management, particularly internationally. Additional studies on the cost-benefit ratio of research investments could inform the allocation of research and operational investments [78].

Factors in the center of our conceptual model, such as science relevancy and accessibility, are perhaps more easily adaptable than others, as change typically occurs on an individual level, as opposed to a societal or institutional level. Studies we reviewed showed that factors on the left side of our conceptual model (e.g., collaboration, relationships) are key to improving science accessibility, relevancy, and trust on an individual level $[12,34,39,43,61]$. Boundary organizations are keys to fostering relationships and collaboration on an institutional level, which ultimately increases the facilitators and reduces the barriers to science use in decision-making [3]. The available literature suggests that boundary organizations in wildland fire management have been successful in facilitating the use of fire science $[13,15]$. Given that fire-related boundary organizations are relatively new, they should continue to be evaluated longitudinally, to understand how they influence collaboration, co-production, and fire science application as they mature $[2 \bullet \bullet]$. As additional boundary organizations develop internationally, they too should be evaluated for effectiveness in facilitating the use of fire science.

The most common barriers to the application of fire science were external factors (e.g., public acceptance, litigation) and funding/capacity (e.g., lack of scientific expertise, time to adopt science). The fact that these factors are commonly mentioned in both time periods suggests that they are persistent and difficult to overcome. Changes in funding/ capacity do not happen often, but when they do occur, they can have profound effects on the use of fire science in management. Examples include the development and growth of predictive services in wildfire management $[67 \bullet \bullet]$, the National Fire Plan in the USA, and the development of boundary organizations $[2,4,56]$. External factors are also slow to change, but change can be precipitated by dramatic events, such as destructive wildfires [64]. To that end, it is critical that scientists and managers are ready to take advantage of rare opportunities for change in capacity and external factors to advance the use of science in decision-making. They can be better prepared for such opportunities by continually fostering all the factors on the left side of our conceptual model.

Acknowledgments The authors acknowledge their institutions for supporting the published work, the Joint Fire Science Program, the USDA Forest Service Rocky Mountain Research Station, and the Ecological Restoration Institute at Northern Arizona University.

\section{Compliance with Ethical Standards}

Conflict of Interest Molly Hunter, Melanie Colavito and Vita Wright declare that they have no conflict of interest.

Human and Animal Rights and Informed Consent This article does not contain any studies with human or animal subjects performed by any of the authors.

\section{Appendix A-General Topic Areas with Articles by Year}

\section{General Fire Science}

- 1987 [27]

- $2001[22,45]$ 
- 2002 [40]

- $2007[36,50]$

- 2008 [39]

- 2010 [14]

- $2011[51]$

- 2012 [62]

- $2013[44,59,79]$

- $2014[80,81]$

- $2015[32,55,82,83]$

- $2016[13,23,34,60]$

- $2017[12,63,84-86]$

- $2018[15 \bullet \bullet]$

- $2019[2,73,75]$

\section{General Land Management}

- 2003 [87]

- 2004 [53]

- 2006 [88]

- $2007[89,90]$

- 2008 [91]

- 2011 [48]

- 2012 [92]

- $2015[42,46]$

- $2017[43,47]$

- $2018[93,94]$

- 2019 [64]

\section{Climate Change}

- 2010 [95]

- $2012[35]$

- $2013[76]$

- $2014[58,68,96,97]$

- $2015[37,41]$

- 2016 [65]

- $2017[57]$

- $2019[66]$

\section{Decision Support Tools}

$$
\begin{array}{ll}
\text { - } & 1986[26] \\
\text { - } & 2010[61] \\
\text { - } & 2011[38,77] \\
\text { - } & 2012[98] \\
\text { - } & 2018[49] \\
&
\end{array}
$$

Open Access This article is licensed under a Creative Commons Attribution 4.0 International License, which permits use, sharing, adaptation, distribution and reproduction in any medium or format, as long as you give appropriate credit to the original author(s) and the source, provide a link to the Creative Commons licence, and indicate if changes were made. The images or other third party material in this article are included in the article's Creative Commons licence, unless indicated otherwise in a credit line to the material. If material is not included in the article's Creative Commons licence and your intended use is not permitted by statutory regulation or exceeds the permitted use, you will need to obtain permission directly from the copyright holder. To view a copy of this licence, visit http://creativecommons.org/licenses/by/4.0/.

\section{References}

Papers of particular interest, published recently, have been highlighted as:

- Of importance

• Of major importance

1. Brunner R, Steelman TA, Coe-Juell L, Cromley CM, Edwards CM, Tucker DW. Adaptive governance: integrating science, policy, and decision making. New York: Columbia University Press; 2005.

2.• Colavito MM, Trainor ST, Kettle NP, York A. Making the transition from science delivery to knowledge coproduction in boundary spanning: a case study of the Alaska Fire Science Consortium. Weather Clim Soc. 2019. https://doi.org/10.1175/WCAS-D-190009.1 This paper is useful for understanding how a boundary organization focused on the development and communication of fire science operates and how it has changed over time.

3. Cash DW, Clark WC, Alcock F, Dickson NM, Eckley N, Guston $\mathrm{DH}$, et al. Knowledge systems for sustainable development. Proc Natl Academy Sciences. 2003;100:8086-91. https://doi.org/10. 1073/pnas.1231332100.

4. Kocher SD, Toman E, Trainor SF, Wright V, Briggs JS, Goebel CP, et al. How can we span the boundaries between wildland fire science and management in the United States? J For. 2012;110:421-8. https://doi.org/10.5849/jof.11-085.

5. McNie EC. Reconciling the supply of scientific information with user demands: an analysis of the problem and review of the literature. Environ Sci Pol. 2007;10:17-38. https://doi.org/10.1016/j. envsci.2006.10.004.

6. Sarewitz D, Pielke RA Jr. The neglected heart of science policy: reconciling supply of and demand for science. Environ Sci Pol. 2007;10:5-16. https://doi.org/10.1016/j.envsci.2006.10.001.

7. White DD, Wutich A, Larson KL, Gober P, Lant T, Senneville C. Credibility, salience, and legitimacy of boundary objects: water managers' assessment of a simulation model in an immersive decision theater. Sci Public Policy. 2010; https://academic.oup.com/jof/ article/109/1/43/4599449;37:219-32.

8. Star SL, Griesemer JR. Institutional ecology, 'translations' and boundary objects: amateurs and professionals in Berkeley's Museum of Vertebrate Zoology, 1907-39. Soc Stud Sci 1989; https://doi.org/10.1177/030631289019003001, 19, 387, 420

9. Lemos MC, Morehouse BJ. The co-production of science and policy in integrated climate assessments. Glob Environmental Change. 2005;15:57-68. https://doi.org/10.1016/j.gloenvcha.2004.09.004.

10. Meadow AM, Ferguson DB, Guido Z, Horangic A, Owen G, Wall T. Moving toward the deliberate coproduction of climate science 
knowledge. Weather Climate Soc. 2015;7:179-91. https://doi.org/ 10.1175/WCAS-D-14-00050.1.

11. Cash DW, Borck JC, Patt AG. Countering the loading-dock approach to linking science and decision making: comparative analysis of El Niño/Southern Oscillation (ENSO) forecasting systems. Sci Technol Human Values. 2006;31:465-94. https://doi.org/10. $1177 / 0162243906287547$.

12.• Colavito MM. The role of science in the Collaborative Forest Landscape Restoration Program. J For. 2017. https://doi.org/10. 5849/jof.15-142 This paper examines how science is applied in collaborative efforts to plan and implement forest restoration under the umbrella of a policy mechanism that requires science-based collaboration.

13. Hunter ME. Outcomes of fire research: is science used? International J Wildland Fire. 2016;25:495. https://doi.org/10.1071/WF15202.

14. Wright V. Influences to the success of fire science delivery: perspectives of potential fire/fuels science users. Joint Fire Science Program 2010. https://www.firescience.gov/projects/04-4-2-01/project/04-4-201_vw_jfsp_final_report.pdf. Accessed 30 Dec 2019.

15.• Maletsky LD, Evans WP, Singletary L, Sicafuse LL. Joint Fire Science Program (JFSP) Fire Science Exchange Network: a national evaluation of initiative impacts. J For. 2018. https://doi.org/10. 1093/jofore/fvy009 This paper presents results from four year longitudinal evaluation survey of the Joint Fire Science Program Fire Science Exchange Network, a fire science boundary organization in the United States. Managers who answered the survey indicated that this boundary organization was a trusted source and enhanced the accessibility of fire science within their regions.

16. Ruane S. Using a worldview lens to examine complex policy issues: a historical review of bushfire management in the South West of Australia. Local Environ. 2018;23:777-95. https://doi.org/10. 1080/13549839.2018.1467390.

17. National Wildfire Coordinating Group. Glossary of wildland fire. National Wildfire Coordinating Group https:/www.nwcg.gov/ glossary/a-z. Accessed 30 Dec 2019.

18. Peterson DL, Johnson MC. Science-basis for strategic planning for hazardous fuel treatment. Fire Manag Today. 2007;67(3):13-8.

19. Stephens SL, Ruth LW. Federal forest-fire policy in the United States. Ecol Appl. 2005;15:532-42. https://doi.org/10.1890/04-0545.

20. Dague D, Hirami P. The United States Forest Service's incident command system 40 years on: from domestic wildfires to international disaster response. Unasylva. 2015;60:79-85.

21. Heffernan R. Who does what: the roles of scientists in wildland fire weather. Fire Manag today. 2017;75(1):6-9 In this popular management article, the author articulates the role of the National Weather Service in disseminating weather and climate science to fire managers. Weather and climate science is disseminated in various projects and used in particular for short- and longterm planning and forecasting.

22. Conard SG, Hartzell T, Hilbruner MW, Zimmerman GT. Changing fuel management strategies - the challenge of meeting new information and analysis needs. International J Wildland Fire. 2001;10: 267. https://doi.org/10.1071/WF01027.

23. Neale T, Weir JK, Dovers S. Science in motion: integrating scientific knowledge into bushfire risk mitigation in Southwest Victoria. Australian J Emergency Manag. 2016;31:13-7.

24. Jahangirian M, Eldabi T, Garg L, Jun GT, Naseer A, Patel B, et al. A rapid review method for extremely large corpora of literature: applications to the domains of modelling, simulation, and management. Int J Information Manag. 2011;31:234 43. https://doi.org/10. 1016/j.ijinfomgt.2010.07.004.

25. Saldana J. The coding manual for qualitative researchers. London: Sage Publications; 2016.

26. Kiil AD, Quintilio D, Alexander ME. 1986. Adaptation of a national system of fire danger rating in Alberta, Canada: a case study in technology transfer. In: Proceedings of the $18^{\text {th }}$ IUFRO World Congress. 1986. https://cfs.nrcan.gc.ca/pubwarehouse/pdfs/11517. pdf Accessed 30 March 2020.

27. Kaage W. Predicting prescribed fire managers' perceptions of their information sources' worth. M.S. Thesis. 1987. University of Montana.

28. Guston DH. Boundary organizations in environmental policy and science: an introduction. Sci Technol Human Values. 2001;26:399408. https://doi.org/10.1177/016224390102600401.

29. Meadow A. An ethnohistory of the NOAA RISA program. Climate Assessment for the Southwest, University of Arizona. 2017. https:// www.climas.arizona.edu/sites/default/files/ pdfmeadow2017risahistory.pdf. Accessed 30 Dec 2019.

30. Jacobson C, Robertson AL. Landscape Conservation Cooperatives: bridging entities to facilitate adaptive co-governance of socialecological systems. Hum Dimens Wildl. 2012;17:333-43. https:// doi.org/10.1080/10871209.2012.709310.

31. Innes, T. Natural resources information management forum: putting knowledge to work. FORREX . 2003. http://citeseerx.ist.psu.edu/ viewdoc/download?doi=10.1.1.7.2353\&rep=rep1\&type=pdf. Accessed 30 Dec 2019.

32. Meyer MD, Roberts SL, Wills R, Brooks M, Winford EM. Principles of effective USA federal fire management plans. Fire Ecology. 2015;11:59-83. https://doi.org/10.4996/fireecology. 1102059.

33. Schultz C, Sisk TD, Noon BR, Nie MA. Wildlife conservation planning under the United States Forest Service's 2012 planning rule. J Wildlife Manag. 2013;77:428-44. https://doi.org/10.1002/ jwmg.513.

34. Neale T, Weir JK, McGee TK. Knowing wildfire risk: scientific interactions with risk mitigation policy and practice in Victoria. Australia Geoforum. 2016;72:16-25. https://doi.org/10.1016/j. geoforum.2016.03.008.

35. Archie KM, Dilling L, Milford JB, Pampel FC. Climate change and western public lands: a survey of U.S. federal land managers on the status of adaptation efforts. Ecol Soc. 2012. https://doi.org/10.5751/ ES-05187-170420.

36. Barbour J. Accelerating adoption of fire science and related research. Joint Fire Science Program. 2007. https://www. firescience.gov/projects/05-S-07/project/05-S-07_final_report.pdf Accessed 30 Dec 2019.

37. Bosomworth K. Climate change adaptation in public policy: frames, fire management, and frame reflection. Environment and Planning C: Government and Policy. 2015;33:1450-66. https://doi. org/10.1177/0263774X15614138.

38. Calkin DC, Finney MA, Ager AA, Thompson MP, Gebert KM. Progress towards and barriers to implementation of a risk framework for US federal wildland fire policy and decision making. For Policy Economics. 2011;13:378-89. https://doi.org/10.1016/j. forpol.2011.02.007.

39. Kalabokidis K, Losifides T, Henderson M, Morehouse B. Wildfire policy and use of science in the context of a socio-ecological system on the Aegean Archipelago. Environmental Sci \& Policy. 2008;11: 408-21. https://doi.org/10.1016/j.envsci.2008.01.006.

40. Kearns S, Wright V. Barriers to the use of science: USFS case study on fire, weed, and recreation management in wilderness. Aldo Leopold Wilderness Research Institute. 2002.

41. Kemp KB, Blades JJ, Klos PZ, Hall TE, Force JE, Morgan P, et al. Managing for climate change on federal lands of the western United States. Ecol Soc. 2015;20. https://doi.org/10.5751/ES-07522200217.

42. Marcot BG, Fisher LA, Thompson MP, Tomosy M. Applying the science of decision making: a survey of use and needs in the national forest system. USDA Forest Service. 2015. https://www.fs. fed.us/emc/nepa/includes/FS SurveyofDecisionScience2015.pdf Accessed 30 Dec 2019. 
43.• Colovito MM. Utilising scientific information to support resilient forest and fire management. Int J Wildland Fire. 2017. https://doi. org/10.1071/WF16158 This paper provides examples of how science is used in forest and fire management and includes recommendations for scientists and managers working to improve the development, application, and communication of science.

44. Davis EJ, Moseley C, Olsen C, Abrams J, Creighton J. Diversity and dynamism of fire science user needs. J For. 2013;111:101-7. https://doi.org/10.5849/jof.12-037.

45. Garfin GM, Morehouse BJ. Facilitating use of climate information for wildfire decision-making in the U.S. Southwest. 2001. https:// www.climas.arizona.edu/sites/default/files/pdfgarfin2001.pdf. Accessed 30 Dec 2019.

46. Cheng A, Gerlak A, Dale L, Mattor K. Examining the adaptability of collaborative governance associated with publicly managed ecosystems over time: insights from the Front Range Roundtable, Colorado. USA Ecology and Society. 2015;20. https://doi.org/10. 5751/ES-07187-200135.

47.• Urgenson LS, Ryan CM, Halpern CB, Bakker JD, Belote RT, Franklin JF, et al. Visions of restoration in fire-adapted forest landscapes: lessons from the Collaborative Forest Landscape Restoration Program. Environ Manag. 2017. https://doi.org/10. 1007/s00267-016-0791-2 This paper presents findings from 86 interviews with participants in collaborative forest restoration projects on challenges and opportunities for adopting sciencebased forest restoration. Engagement of science was identified as one factor that facilitates the goals of collaborative forest restoration groups.

48. Jacobi WR, Crump A, Lundquist JE. Dissemination of Forest Health Research Information in the Rocky Mountains. J For. 2011. https://doi.org/10.1093/jof/109.1.43.

49. Milford JB, Knight D. Increasing the use of earth science data and models in air quality management. J Air \& Waste Manag Assn. 2017;67:431-44. https://doi.org/10.1080/10962247.2016. 1248303 .

50. Morford S, Hollstedt C. Revisiting a forest extension strategy for British Columbia: a survey of natural resource practitioners and information providers. Ministry of Forests and Range Forest Science Program. 2007. https://www.for.gov.bc.ca/hfd/pubs/Docs/ $\mathrm{Tr} / \mathrm{Tr}$ 042.pdf Accessed 30 Dec 2019.

51. Ryan CM, Cerveny LK. Wildland fire science for management: federal fire manager information needs, sources, and uses. Western J Applied For. 2011;26:126-32. https://doi.org/10.1093/ wjaf/26.3.126.

52. Kennedy JJ, Haynes RH, Zhou X. Line officers' views on stated USDA Forest Service values and the agency reward system. USDA Forest Service. 2005. https://www.fs.fed.us/pnw/pubs/pnw_gtr632. pdf Accessed 30 Dec 2019.

53. Wright V. Barriers to science-based management: what are they and what can we do about them? In Proceedings of the 2003 George Wright Society / National Park Service Joint Conference. 2004 The George Wright Society http://wwwgeorgewrightorg/ 0310wrightpdf Accessed 30 Dec 2019.

54. Weick KE, KM Sutcliffe. Managing the unexpected: assuring high performance in an age of complexity. 2011. San Francisco: John Wiley and Sons.

55. Wright $\mathrm{V}$. Individual and organizational influences on fire research use by federal fire managers and decision makers in the Bureau of Land Management, National Park Service, and U.S. Forest Service. Ph.D. Dissertation. 2015. University of Montana.

56. Garvin DA. Edmonsdson A, Gino F. Is yours a learning organization? Harvard Business Review. 2001; March:1-10.

57. Allen E, Stephens J, Yorgey G, Kruger C, Ahamed S, Adam J. Climate science information needs among natural resource decision-makers in the Northwest US. Climate Services. 2017. https://doi.org/10.1016/j.cliser.2017.03.002.

58. Archie KM, Dilling L, Milford JB, Pampel FC. Unpacking the 'information barrier': comparing perspectives on information as a barrier to climate change adaptation in the Interior Mountain West. J Environmental Manag. 2014;133:397-410. https://doi.org/10. 1016/j.jenvman.2013.12.015

59. Chen X, Emery N, Garcia ES, Hanan EJ, Hodges HE, Martin T, et al. Perspectives on disconnects between scientific information and management decisions on post-fire recovery in Western US. Environ Manag. 2013;52:1415-26. https://doi.org/10.1007/ s00267-013-0165-y.

60. Garfin G, Brown TJ, Wordell T, Delgado E. The making of national seasonal wildfire outlooks. In: Climate in Context. San Francisco: John Wiley \& Sons, Ltd.; 2016. https://doi.org/10.1002/ 9781118474785.ch7.

61. Morehouse BJ, O'Brien S, Christopherson G, Johnson P. Integrating values and risk perceptions into a decision support system. Intl J Wildland Fire. 2010;19:123. https://doi.org/10.1071/ WF08064.

62. Owen G, McLeod JD, Kolden CA, Ferguson DB, Brown TJ. Wildfire management and forecasting fire potential: the roles of climate information and social networks in the Southwest United States. Weather Climate Society. 2012;4:90-102. https://doi.org/ 10.1175/WCAS-D-11-00038.1.

63.• Wall TU, Brown TJ, Nauslar NJ. Spot weather forecasts: improving utilization, communication, and perceptions of accuracy in sophisticated user groups. Weather Clim Soc. 2017. https://doi.org/10. 1175/WCAS-D-15-0055.1 Through interviews with fire practitioners, this paper documents to use and interpretation of spot weather forecasts in fire management. Trust in and appropriate use of spot weather forecasts is improved when there are strong professional relationships between fire practitioners and meteorologists.

64. White EM, Lindberg K, Davis EJ, Spies TA. Use of science and modeling by practitioners in landscape-scale management decisions. J For. 2019;117:267-79. https://doi.org/10.1093/jofore/ fvz007.

65. Blades JJ, Klos PZ, Kemp KB, Hall TE, Force JE, Morgan P, et al. Forest managers' response to climate change science: evaluating the constructs of boundary objects and organizations. Forest Ecology and Manage. 2016;360:376-87. https://doi.org/10.1016/j. foreco.2015.07.020

66. Rutherford T, Schultz C. Adapting wildland fire governance to climate change in Alaska. Ecol Soc. 2019;24. https://doi.org/10. 5751/ES-10810-240127.

67.• Neale T, May D. Bushfire simulators and analysis in Australia: insights into an emerging sociotechnical practice. Environmental Hazards. 2018. https://doi.org/10.1080/17477891.2017.1410462 This paper provides a history of bushfire simulators in Australia and a review of studies on their use. The paper also presents needs for future research on the adoption of bushfire prediction systems.

68. Archie KM. Mountain communities and climate change adaptation: barriers to planning and hurdles to implementation in the Southern Rocky Mountain region of North America. Mitig Adapt Strateg Glob Chang. 2014;19:569-87. https://doi.org/10.1007/s11027013-9449-z.

69. Djenontin INS, Meadow AM. The art of co-production of knowledge in environmental sciences and management: lessons from international practice. Environmental Manag. 2018;61:885-903. https://doi.org/10.1007/s00267-018-1028-3.

70. Bremer S, Meisch S. Co-production in climate change research: reviewing different perspectives. WIREs Clim Change. 2017;8. https://doi.org/10.1002/wcc.482. 
71. Wall TU, Meadow AM, Horganic A. Developing evaluation indicators to improve the process of coproducing usable climate science. Weather Climate Society. 2017;9:95-107. https://doi.org/10. 1175/WCAS-D-16-0008.1.

72. Kettle NP. Knowledge co-production in contested spaces: an evaluation of the North Slope Borough - shell baseline studies program. ARCTIC. 2019. https://doi.org/10.14430/arctic67804.

73. Schultz C, McCaffrey SM, Huber-Stearns HH. Policy barriers and opportunities for prescribed fire application in the western United States. Intl J Wildland Fire. 2019;28:874. https://doi.org/10.1071/ WF19040.

74. Colavito MM, Wasserman TN, Vosick D. All-Lands Planning, Coordination, and Wildfire Risk Reduction Project Report. Northern Arizona University Ecological Restoration Institute. $2018 \mathrm{https}: / / \mathrm{cdm} 17192$. contentdm.oclc.org/digital/collection/ p17192coll1/id/913/rec/2/ Accessed 30 Dec 2019. This report summarizes an effort to communicate a wildfire risk assessment tool to potential end users and provides results from an evaluation of the communication process.

75.• Sherry J, Neale T, McGee TK, Sharpe M. Rethinking the maps: a case study of knowledge incorporation in Canadian wildfire risk management and planning. J Environmental Manag. 2019. https:// doi.org/10.1016/j.jenvman.2018.12.116 This paper presents findings from interviews with wildfire managers in Alberta, Canada on their perceptions of science and the use of science in decision-making. Perceptions of science among wildfire managers have been shaped by individual and institutional values and priorities.

76. Cross MS, McCarthy PD, Garfin G, Gori D, Enquist CAF. Accelerating adaptation of natural resource management to address climate change. Conserv Biol. 2013;27:4-13. https://doi.org/10. 1111/j.1523-1739.2012.01954.x.

77. Pence M, Zimmerman T. The wildland fire decision support system: integrating science, technology, and fire management. Fire Management Today. 2011;71(1):18-22.

78. Gould JS, Patriquin MN, Wang S, McFarlane B, Wotton BM. Economic evaluation of research to improve the Canadian Forest Fire Danger Rating System. Forestry. 2012;86:317-29. https:/doi. org/10.1093/forestry/cps082.

79. Smith R, Lee ME, Kim YS. Joint Fire Science Program publications survey - feedback from fire professionals. Joint Fire Science Program. 2013. https://www.firescience.gov/projects/11-C-01-02/ project/11-C-01-02_final_report.pdf Accessed 30 Dec 2019.

80. Clayton H, Mylek MR, Schirmer J, Cary GJ, Dovers SR. Exploring the use of economic evaluation in Australian wildland fire management decision-making. Intl J Wildland Fire. 2014;23:555. https:// doi.org/10.1071/WF13140.

81. Robichaud PR, Rhee H, Lewis SA. A synthesis of post-fire burned area reports from 1972 to 2009 for Western US Forest Service lands: trends in wildfire characteristics and post-fire stabilisation treatments and expenditures. Intl J Wildland Fire. 2014;23:929. https://doi.org/10.1071/WF13192.

82. Kulig JC, Westlund R, et al. Soc Nat Resour. 2015;28:908-17. https://doi.org/10.1080/08941920.2015.1037876.

83. Smith JK. Strengthening syntheses on fire: increasing their usefulness for managers. USDA Forest Service. 2015. https://doi.org/10. 2737/RMRS-GTR-337 Accessed 30 Dec 2019.

84. Adams TT, Butler BW, Brown S, Wright V, Black A. Bridging the divide between fire safety research and fighting fire safely: how do we convey research innovation to contribute more effectively to wildland firefighter safety? Int J Wildland Fire. 2017. https://doi. org/10.1071/WF16147 In this commentary, authors discuss the use of science to inform fire fighter safety, using the adoption of the science of fire fighter safety zones as a case study.
85. Otero L, Nielsen JO. Coexisting with wildfire? Achievements and challenges for a radical social-ecological transformation in Catalonia (Spain). Geoforum. 2017;85:234-46. https://doi.org/10. 1016/j.geoforum.2017.07.020.

86. Weir JK, Neale T, Clark L. Science is critical but it's not everything: our findings. In: proceedings from the Bushfire and Natural Hazards CRC \& AFAC conference. 2017. This paper presents summary findings from projects investigating the role of science in making fire risk reduction decisions in Australia. The authors argue that while scientific information is critical in this context, managers and policy makers must also acknowledge the importance of other forms of knowledge.

87. Joyce L. Improving the flow of scientific information across the interface of forest science and policy. Forest Policy Econ. 2003;5: 339-47. https://doi.org/10.1016/S1389-9341(03)00033-9.

88. Wright V. Overcoming barriers to the use of science in National Parks. In: Proceedings of the 2005 George Wright Society Conference on Parks, Protected Areas, and Cultural Sites. 2006. The George Wright Society. http://www.georgewright.org/ 0568wright.pdf Accessed 30 Dec 2019.

89. Wright V. Communication barriers to applying federal research in support of land management in the United States. In: Proceedings: international conference on transfer of forest science knowledge and technology. U.S. Forest Service Pacific Northwest Research Station. 2007. https://www.fs.fed.us/rm/pubs_other/rmrs_2007 wright v001.pdf Accessed 30 Dec 2019.

90. Yougblood A, Bigler-Cole H, Fettig CJ, Fiedler C, Knapp EE, Lehmkuhl JF, et al. Making fire and fire surogate science available: a summary of regional workshops with clients. USDA Forest Service. 2007. https://doi.org/10.2737/PNW-GTR-727.

91. Corringham TW, Westerling AL, Morehouse BJ. Exploring use of climate information in wildland fire management. USDA Forest Service. 2008. https://www.fs.fed.us/rm/pubs/rmrs_p042/rmrs p042_603_613.pdf Accessed 30 Dec 2019.

92. Driscoll CT, Lambert KF, III Chapin FS, Nowak DJ, Spies TA, Swanson FJ, Kittredge DB, Hart CM. Science and society: the role of long-term studies in environmental stewardship. BioScience. 2012;62:354-66. https://doi.org/10.1525/bio.2012.62.4.7.

93. Ryan CM, Cerveny LK, Robinson TL, Blahna DJ. Implementing the 2012 Forest planning rule: best available scientific information in forest planning assessments. For Sci. 2018;64:159-69. https:// doi.org/10.1093/forsci/fxx004.

94. Esch BE, Waltz AEM, Wasserman TN, Kalies EL. Using best available science information: determining best and available. $\mathrm{J}$ For. 2018;116:473-80. https://doi.org/10.1093/jofore/fvy037.

95. Kolden CA, Brown TJ. Beyond wildfire: perspectives of climate, managed fire and policy in the USA. Intl J Wildland fire. 2010;19: 364. https://doi.org/10.1071/WF08111.

96. Raftoyannis Y, Nocentini S, Marchi E, Sainz RC, Guemes CG, Pilas I, et al. Perceptions of forest experts on climate change and fire management in European Mediterranean forests. IForest Biogeosciences and Forestry. 2014;7:33-41. https://doi.org/10. 3832/ifor0817-006.

97. Lackstrom K, Kettle NP, Haywood B, Dow K. Climate-sensitive decisions and time frames: a cross-sectoral analysis of information pathways in the Carolinas. Weather Climate Society. 2014;6:23852. https://doi.org/10.1175/WCAS-D-13-00030.1.

98. Roncoli C, Breuer N, Zierden D, Fraisse C, Broad K, Hoogenboom $\mathrm{G}$. The art of the science: climate forecasts for wildfire management in the southeastern United States. Clim Chang. 2012;113:1113-21. https://doi.org/10.1007/s10584-012-0526-1.

Publisher's Note Springer Nature remains neutral with regard to jurisdictional claims in published maps and institutional affiliations. 